\section{International Scientific Journal Theoretical \& Applied Science}

p-ISSN: 2308-4944 (print) e-ISSN: 2409-0085 (online)

Year: $2018 \quad$ Issue: $06 \quad$ Volume: 62

Published: $30.06 .2018 \quad$ http://T-Science.org

SECTION 11. Biology. Ecology. Veterinary.
Victor Goldade

Dr. Sci. (Eng.), Professor,

V.A. Belyi Metal-Polymer Research Institute of National Academy of Sciences of Belarus; Francisk Skorina Gomel State University,

Gomel, Belarus victor.goldade@gmail.com

Vladimir Zhukalov senior lecturer, University of Civil Protection of the Ministry for Emergency Situations of the Republic of Belarus Gomel, Belarys jukalov@mail.ru

Sergey Zotov

$\mathrm{PhD}$, leading scientific researcher, V.A. Belyi Metal-Polymer Research Institute of National Academy of Sciences of Belarus, Gomel, Belarus zotov-1969@mail.ru

\title{
FIBROUS SORBENTS FOR GATHERING OF OIL AND PETROLEUM PRODUCTS
}

\footnotetext{
Abstract: A review of scientific and technical literature on mitigation of oil and petroleum products spill impact, and the results of personal studies by the authors on creation of sorbing materials for collecting and extraction of petroleum products from the surface of soils and water bodies are presented. Special attention is paid to the polymer fibrous sorbents produced by melt blowing in view of their acceptable indicators by efficiency vs price criterion.

Key words: oil and petroleum products, emergency spills, ecological aftermath, sorbents, melt blowing technology.

Language: English

Citation: Goldade V, Zhukalov V, Zotov S (2018) FIBROUS SORBENTS FOR GATHERING OF OIL AND PETROLEUM PRODUCTS. ISJ Theoretical \& Applied Science, 06 (62): 139-149.

Soi: http://s-o-i.org/1.1/TAS-06-62-26 Doi: crossef https://dx.doi.org/10.15863/TAS.2018.06.62.26
}

\section{INTRODUCTION}

Oil and petroleum products $(\mathrm{PeP})$ spills on the surface of water bodies and soils are one of the most dangerous types of man-made environmental disasters. Spilled toxic substances destroy animals and plants and make the contaminated areas uninhabitable for many years. Ecological consequences of oil spills are very difficult to estimate as oil contamination disrupts many natural processes and interrelations, significantly changes the habitability conditions of all types of living organisms and is accumulated in the biomass.

Oil is a long-term decaying product and, when a man-made disaster happens in water areas, it spreads very quickly over the water surface forming a dense layer of oil film which obstructs the access of air and light. The International Petroleum Industry Environmental Conservation Association states that such disasters do not result in immediate mass mortality in fishes, reptiles, animals and plants. However, in the medium- and long-term perspective the influence of oil spills is extremely negative. The effect of spills is the most severe for the organisms living in the coastal waters, especially the ones living on the seabed or on the surface.

Modern technologies for fighting large-scale oil spills are not always effective. Floating booms, special oil collecting vessels, sorbents, chemicals capable to "decompose" the oil or turn it into a gel (to make the collection process easier) are used. However, certain chemical agents applied for fighting such disasters are extremely toxic themselves. Nowadays, active developments are carried out in the area of creating new synthetic sorbents which meet (to a maximum degree) the integrated "price vs efficiency" criterion. Besides, the equipment allowing to carry out effective gathering of petroleum products from water surface and to directly separate (at site) water from oil is being developed. 


\begin{tabular}{|c|c|c|c|c|c|c|}
\hline Impact Factor: & $\begin{array}{l}\text { ISRA (India) } \\
\text { ISI (Dubai, UAE } \\
\text { GIF (Australia) } \\
\text { JIF }\end{array}$ & $\begin{array}{r}=1.344 \\
=0.829 \\
=0.564 \\
=1.500\end{array}$ & $\begin{array}{l}\text { SIS (USA) } \\
\text { PИНЦ (Russia) } \\
\text { ESJI (KZ) } \\
\text { SJIF (Morocco }\end{array}$ & $\begin{array}{l}=0.912 \\
=0.207 \\
=4.102 \\
=\mathbf{2 . 0 3 1}\end{array}$ & $\begin{array}{l}\text { ICV (Poland) } \\
\text { PIF (India) } \\
\text { IBI (India) }\end{array}$ & $\begin{array}{l}=6.630 \\
=1.940 \\
=4.260\end{array}$ \\
\hline
\end{tabular}

\section{PETROLEUM PRODUCTS GATHERING METHODS}

Various methods are used to gather and extract oil and PeP from the water surface. They can be conventionally divided into mechanical, thermal, physical-chemical and microbiological methods (Fig. 1).
Thermal method which is based on oil layer burning out is used when the layer thickness is sufficient and immediately after contamination before the emulsions with water are formed. As a rule, it is combined with other methods for spill elimination. Burning of spilled oil is the oldest way of cleaning the water surface.

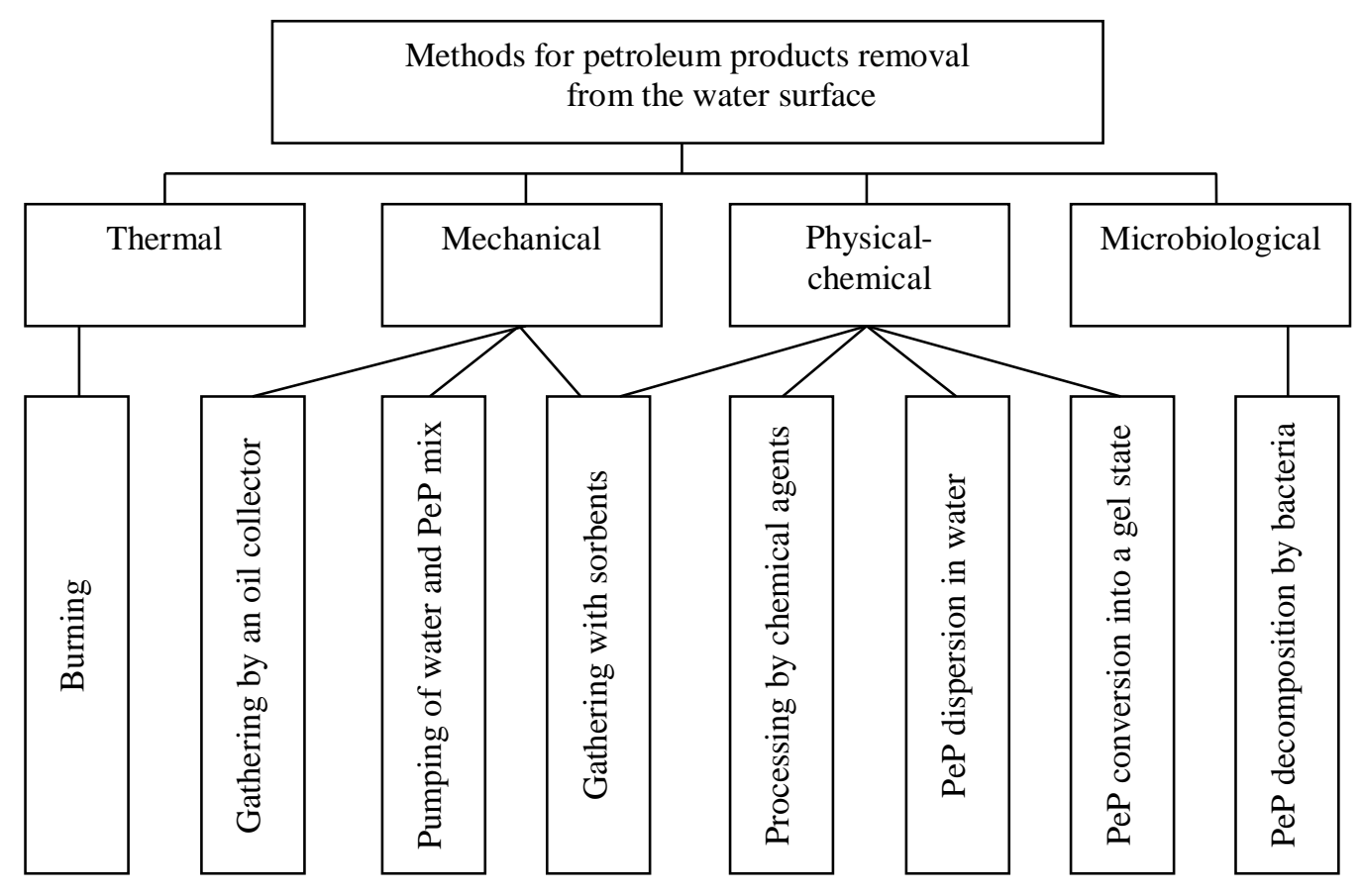

Figure 1 - Classification of methods for petroleum products gathering and extraction from the water surface [1-6]

The most obvious disadvantage of using this method of contamination elimination is that it forms huge clouds of soot and other (much more toxic) compounds resulting in heavy pollution of the air environment around the oil spill. Another limitation of this method is that it does not provide for complete cleaning of the surface from heavy petroleum products, and sometimes it is even impossible to start a fire on a thin film of petroleum products [7].

Mechanical method is the most rational way to remove petroleum products from the surface of not only reservoirs, but water streams as well. Mechanical gathering and pumping of oil and petroleum products is made by oil-collecting devices or directly by pumps from natural or artificial cavitations of the ground surface, wells or trenches (oil traps). This is the most effective way to remove the dissolved light hydrocarbons.

Physical-chemical methods using dispersants and sorbents are viewed to be effective when mechanical gathering of petroleum products is impossible, for example, when film thickness is small or when the spilled petroleum products pose real threats to the most ecologically vulnerable areas [8].

Biochemical treatment of the water surface to remove spilled oil is still not widespread due to poor biodegradability of oil components and long duration of decomposition process (up to 6 months) [9-11]. However, this trend has gained momentum in recent years [12]. Nowadays, the microbiological method for elimination of large-scale contamination of soils and water bodies with oil is used in combination with mechanical gathering and physico-chemical methods of hydrocarbons localization when the film thickness is not less than $0.1 \mathrm{~mm}$. At the same time microorganisms are capable to utilize the emulsified and dissolved petroleum products. Long duration of biological degradation process is the limitation to the application of microbial neutralization of the oilcontaminated environments. The main advantages of microbiological destruction over other methods are better treatment, ecological safety, relatively low costs, possibility to continuously process the "chronic" pollutions and possibility to use it in the areas that are difficult to access. 
Assessment of the existing methods allows to identify the most perspective directions. This is, first of all, PeP extraction using sorbents. The use of sorbing materials is the most effective way to eliminate the effects of oil contamination. For the oil film with thickness of less than 1-2 mm or a shallow water body, sorbents allow to clean the water surface from oil in a very short time at low cost. Quality of sorbents is determined, mainly, by their sorbent capacity with respect to oil, degree of hydrophobicity, floatability (both in the initial state and after sorption of petroleum products), possibility of oil desorption, regeneration and disposal of sorbent, technological effectiveness of their production and application.

\section{SORBENTS FOR GATHERING OF OIL AND PETROLEUM PRODUCTS FROM THE SURFACE OF WATER BODIES}

Materials used for gathering of oil and petroleum products from the surface of water bodies are commonly referred to as oil sorbents, as well as oil collectors and oil absorbers. Three main indicators are used to determine the quality of oil sorbents: oil absorption, water absorption and floatability. Efficiency of sorbents for oil gathering is estimated, first of all, by the value of oil absorption (oil capacity). High water absorption can be eliminated practically for all materials by additional hydrophobicity. Materials with low floatability can be effectively used in products with the reinforcing shell - booms, mats, napkins, etc. Various raw materials are used for oil sorbents production.

Materials capable to absorb and retain oil and PEP on its surface are increasingly applied in the worldwide practice to remove petroleum products from water. These materials can be classified by different categories, in particular: natural and synthetic, mineral and organic, natural and modified [13].

Different types of clays, diatomite rocks (mainly, friable diatomaceous earth), sand, zeolites, tuffs, pumice stone, etc. refer to inorganic sorbents for absorption of oil and its components [14-16]. Clay and diatomites constitute the majority of products in the sorbents' market due to their low cost and possibility of large-scale production. Sand used as a filling material for combating small spills of oil and petroleum products can also be related to this category. However, quality of inorganic sorbents is not at the high level from the point of view of ecological safety. First of all, their oil capacity is low (70-150\%) and they are not good at retaining light fractions, such as gasoline, kerosene, diesel fuel. When eliminating oil spills on water, the inorganic sorbents go down together with oil without addressing the problems of water treatment to remove pollutants. Finally, washing of these sorbents with extractive agents or water with SAS, as well as their burning-out are virtually the only methods of their disposal [17].

Besides, the materials produced by processing rocks and sedimentary rocks (expanded perlite, expanded-clay aggregate, basalt cotton wool) are related to mineral sorbents [16]. In order to achieve the required hydrophobicity properties at the surface of such sorbents, they are often processed with chemical agents: silicone fluids, vapors of mineral oils and paraffins, organic amines with aliphatic or aromatic hydrocarbon chain. However, when using the non-modified mineral sorbents there is a danger that their particles will sink together with the absorbed oil, and decomposition of the sunken oil is extremely slow and has negative impacts on the flora and fauna of water bodies [1, 18].

Natural organic and organo-mineral sorbents are a promising type of sorbents for oil pollution elimination. Wood chips, sawdust, modified peat, dried grain products, wool, waste paper are the most frequently used materials. Wool is one of the best natural sorbents which is comparable in its oil capacity to the modified peat. It can absorb up to 8$10 \mathrm{~kg}$ of oil per kilogram of its mass; at the same time, natural elasticity of wool allows to squeeze out much of the light fractions of oil. However, after several such squeezings the wool turns into the bituminous felt and becomes unsuitable for use. Because of its high price, insufficient quantity and strict requirements to storage (wool is very attractive to rodents, insects and undergoes biochemical transformations) the wool cannot be considered as a promising large-scale oil sorbent at all. Besides, natural organic sorbents are significantly inferior to inorganic and synthetic sorbents on sorbing capacity. However, their application is linked with the need to deliver them in large quantities to the place of localization which affects both the final costs and the time for starting the activities. Their limited floatability (which is considerably inferior to floatability of inorganic and synthetic sorbents) is also an important factor.

The synthetic sorbing materials are mostly produced based on carbamide formaldehyde resins, polyvinyl chloride, nylon, lavsan, Nitron, polypropylene, as well as the natural and synthetic latexes, rubber resins and rubbers made in the form of powder, fibrous material, various foam plastics [19-25]. Hydrophobization is used to increase floatability and oil capacity of this type of sorbents. Some existing methods of hydrophobization for fibrous materials are rather difficult to perform, technological process requires significant amounts of flammable solvents, thus increasing fire and explosion hazards of the processes. Runoff of the part of absorbed petroleum products (sometimes - up to $60-70 \%$ ) when the sorbent is extracted from the 
water surface is a significant drawback of the majority of fibrous sorbents [26-29].

Synthetic oil sorbents are used in the countries with the advanced petrochemical industry (USA, EU countries, Japan). Most commonly, they are made of the polypropylene fibers which are formed into nonwoven rolled fabrics of different thickness. Besides, polyurethane in the spongy or granulated form, formed polyethylene with polymer fillers and other types of plastics are used. At the same time, their application in the form of high-dispersed powders to increase efficiency of the use on thin films is inadmissible due to the risk of cancerogenic diseases. On the other hand, the use of different synthetic materials which have (along with the large pore volume) a rigid three-dimensional lattice pattern is of great interest for wastewater treatment. Polyurethane foam (PPU) polyfoams possess rather high sorption properties [21, 30, 31]. Their oil capacity is 6-8 $\mathrm{kg} / \mathrm{kg}$. One of their drawbacks is that polyurethane polyfoams absorb water in the conditions of increased salinity.

Actually, sorbents, both natural and synthetic (e.g. perlite, vermiculite, zeolite) can absorb in their porous structure only up to $0.2-0.3 \mathrm{~g}$ of oil per $1 \mathrm{~g}$ of sorbent, however, owing to adhesion the amount of oil retained at the sorbents increases manifoldly. The sorbents can be modified to improve their adhesive properties. So, the perlite treated with organosilicon compounds collects up to 6-9 g/g of oil. One gram of hydrophobizated basalt fiber is capable to retain up to $50-60 \mathrm{~g}$ of light petroleum products. Heavy sorbents, such as zeolite and vermiculite, can be used for oil sinkage, while the light ones - for formation (on the surface of water and soil) of an oil-saturated sorbent layer with subsequent removal of this layer and its concentration in the places of oil disposal and destruction.

Sorbents based on different wastes of agricultural and wood-processing industries are represented by various products. They are produced on the basis of sawdust, buckwheat peel and many other crops, peat and other vegetable-based materials [32-37]. All these sorbents possess rather high oil capacity (3-5 kg/kg and higher), they are inexpensive and have a large source of raw materials. However, their main components are cellulose and lignine which impart the surfaces with strong hydrophilic properties. Therefore, sorbents, which possess the extended surface, easily and quickly absorb oil and petroleum products; at the same time, they absorb moisture even better which has an adverse effect on the oil capacity. Thus, it is necessary to impregnate the adsorbent after its deep drying with waterproofing compounds. Hydropobization of the surface by reactant or physico-chemical treatment considerably improves technological parameters but makes the sorbent more expensive. The time of protective action of coatings, and, therefore, the sorbent shelf life is usually limited to less than two years. Sufficiently complete regeneration of the exhausted sorbents of this type is difficult, as squeezing (which allows to perform regeneration at $70-85 \%$ ) breaks the sorbent structure and application of thermal methods is limited to the material thermal stability (usually $250-300{ }^{\circ} \mathrm{C}$ ).

Properties of some materials which are used at gathering of oil or form the basis for producing oil sorbents are given in Table 1 [38].

Properties of different materials for gathering oil

Table 1

\begin{tabular}{|c|c|c|c|}
\hline Material & Oil absorption, g/g & $\begin{array}{c}\text { Water- } \\
\text { absorption, g/g }\end{array}$ & $\begin{array}{l}\text { Oil press } \\
\text { ratio, } \%\end{array}$ \\
\hline \multicolumn{4}{|c|}{ Natural organic materials } \\
\hline Wheat straw (broken grain) & 4.1 & 4.3 & 36 \\
\hline $\begin{aligned} \text { Broken cane: } & \text { - leaves } \\
& \text { - stalks }\end{aligned}$ & $\begin{array}{l}6.1 \\
2.7\end{array}$ & $\begin{array}{l}4.6 \\
3.9\end{array}$ & $\begin{array}{l}31 \\
17\end{array}$ \\
\hline Buckwheat peel & $3.0-3.5$ & 2.2 & 44 \\
\hline Aspen / pine bark & $0.5 / 0.3$ & $0.8 / 0.8$ & $25 / 0$ \\
\hline Sawdust & 1.7 & 4.3 & $10-20$ \\
\hline Lignin hydrolised & $1.5-3.0$ & 4.1 & 25 \\
\hline Wastes of cottonwool production & 8.3 & 0.26 & 60 \\
\hline Peat & 17.7 & 24.3 & 74 \\
\hline Dry moss & $3.5-5.8$ & $3.1-3.5$ & - \\
\hline Wool & $8.0-10.0$ & 4.5 & 87 \\
\hline Crushed brown coal & $1-2$ & 0.2 & - \\
\hline Macroporous technical carbon & $4.0-4.5$ & $0-1.0$ & $10-81$ \\
\hline \multicolumn{4}{|c|}{ Synthetic organic materials } \\
\hline $\begin{aligned} \text { Expanded polystyrene: } & \text { - granules } \\
& \text { - fiber }\end{aligned}$ & $\begin{array}{c}9.3 \\
7.0-12.0\end{array}$ & $\begin{array}{c}4.5 \\
6.0-11.5\end{array}$ & $\begin{array}{c}0 \\
80-90\end{array}$ \\
\hline
\end{tabular}




\begin{tabular}{|c|c|c|c|c|c|c|}
\hline Impact Factor: & $\begin{array}{l}\text { ISRA (India) } \\
\text { ISI (Dubai, UAE } \\
\text { GIF (Australia) } \\
\text { JIF }\end{array}$ & $\begin{array}{r}=1.344 \\
=0.829 \\
=0.564 \\
=1.500\end{array}$ & $\begin{array}{l}\text { SIS (USA) } \\
\text { PИНЦ (Russia) } \\
\text { ESJI (KZ) } \\
\text { SJIF (Morocco) }\end{array}$ & $\begin{array}{l}=0.912 \\
=0.207 \\
=4.102 \\
=\mathbf{2 . 0 3 1}\end{array}$ & $\begin{array}{l}\text { ICV (Poland) } \\
\text { PIF (India) } \\
\text { IBI (India) }\end{array}$ & $\begin{array}{l}=6.630 \\
=1.940 \\
=4.260\end{array}$ \\
\hline
\end{tabular}

\begin{tabular}{|c|c|c|c|}
\hline $\begin{array}{c}\text { Polypropylene: - granules } \\
\text { - fiber }\end{array}$ & $\begin{array}{c}1.6 \\
12-40\end{array}$ & $\begin{array}{l}0.8 \\
1-6\end{array}$ & $\begin{array}{c}0 \\
40-80 \\
\end{array}$ \\
\hline Shredded tires & 3.6 & 7.2 & 55 \\
\hline Rubber crumb & 5.1 & 0.3 & 0 \\
\hline $\begin{aligned} \text { Carbamide-formaldehyde resin: } \\
\text { - pieces } \\
\text { - powder }\end{aligned}$ & $\begin{array}{l}23.3 \\
39.6\end{array}$ & $\begin{array}{l}0.1 \\
0.1\end{array}$ & $\begin{array}{c}0 \\
60\end{array}$ \\
\hline Phenol formaldehyde resin (powder) & 4.4 & 14.5 & 0 \\
\hline $\begin{array}{ll}\text { Foam plastic: } & \text { - sheet } \\
& \text { - granulated }\end{array}$ & $\begin{array}{c}14.5-35.2 \\
36.9\end{array}$ & $\begin{array}{c}1.3-25.9 \\
30.7\end{array}$ & $\begin{array}{c}75-85 \\
-\end{array}$ \\
\hline Polyester batting & 46.3 & $42-52$ & 94 \\
\hline Lavsan (fiber) & $4.7-14.1$ & $4.3-13.9$ & $60-82$ \\
\hline \multicolumn{4}{|c|}{ Inorganic materials } \\
\hline Foamed nickel & 2.9 & 3.0 & 0 \\
\hline Fiber glass & 5.4 & 1.7 & 60 \\
\hline Modified graphite & $40.0-60.0$ & $0.5-10.0$ & $10-65$ \\
\hline Perlite & $5.0-7.0$ & 0.5 & 0 \\
\hline Modified basalt fiber & 37 & 0.5 & 27 \\
\hline
\end{tabular}

\section{SORBENTS BASED ON FIBROUS- POROUS POLYMER MATERIALS}

Fibrous materials represent a system of chaotically arranged thin threads which are freely distributed in space. As a rule, their structure is not spatially oriented, thus allowing the pollutions to contact a large surface per time unit. Cotton wool, felt, fabrics, polyester batting, basalt fiber, etc. are typical fibrous materials for oil collection. In the course of oil absorption, the sorbent fibers are capable to move apart, thus creating a specific sorbent-PEP structure which (after gathering is completed) starts to gradually compress by gravity and to strain off up to $20-25 \%$ of the collected petroleum product. According to the data in Table 1, all fibrous sorbents are characterized by high ratio of the absorbed oil squeezing. Some absorbers with fibrous structure demonstrate a rather high water absorption (polyester batting, sheet foam plastic with thickness of $18 \mathrm{~mm}$ ) which is caused by low hydrophobicity of the surface. This disadvantage can be eliminated by introduction of special hydrophobization additives.

Emergency cleaning of water bodies is an important practical application of fibrous melt-blown materials (i.e. the ones produced by pneumoextrusion method) [39, 40]. Oil-retaining capacity of such materials (which is defined by the nature and structural parameters of fibrous matrix) reaches 10 $\mathrm{g} / \mathrm{g}$ and more. The melt-blown sorbents made in the form of rolls, mats, floating pillows serve as a means to remove oil from the water surface, protect the water body coasts and gather the petroleum products which have spilled onto the soil up to several hundred square meters. High degree of extraction of the emulsified petroleum oil (60-90\%) is observed even in the tough dynamic modes of filtering the oilcontaminated water through the melt-blown material.
Oil trapping occurs not only due to their adsorption on the surface of fibers, but also by retaining the coagulating microdrops in the material pore space. Melt-blown sorbents are produced by using granulated polyethylene, polypropylene, polyethylene terephthalate, as well as secondary thermoplastics (product of recycling the plastic vessels, utensils, packages, etc.).

\subsection{Melt blowing technology}

The melt blowing technological process (Fig. 2) traditionally includes operations on processing the granulated thermoplastic polymer in an extruder, dispersion of the melt being formed with a flow of compressed gas and application of the fiber-porous layer onto the rotating substrate (drum). The fibers generator, manipulator and the mechanism for material removal are the main technological nodes used at melt blowing. The fibers generator which includes an extruder and a pneumatic spraying head is intended for processing the granulate into the melt, forming the fibers out of it and transferring them to the forming substrate. The manipulator ensures rotary and reciprocating movement of the substrate which is required to produce fiber-porous products of the given configuration. Usually, melt blowing is exercised under temperature ranges which ensure the melt viscosity at the extrusion head outlet corresponding to the melt flow index of not less than $20 \mathrm{~g} / 10 \mathrm{~min}$. This value is used as a criterion to establish distribution of temperatures along the extruder zones [41]. The most important operation is the dispersion (spraying) of the melt and fiber drawing with the gas flow. When the temperature conditions are stabilized, the spraying is controlled by adjusting the temperature and compressed air pressure. External electrization may be applied to the fibers being created. 


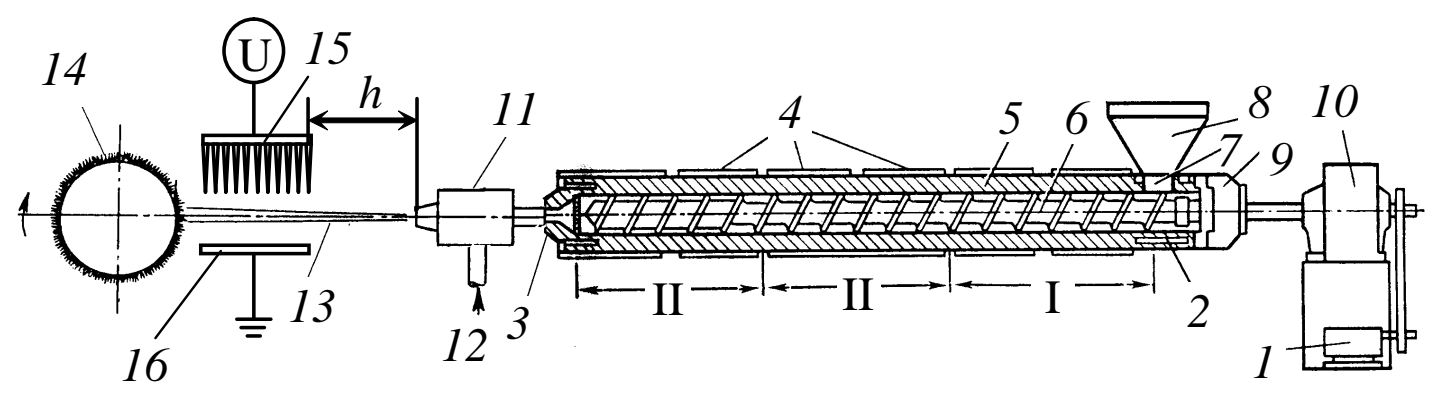

Figure 2 - Diagram of the melt blowing technological process: 1 - engine; 2 - channel for bunker zone cooling; 3 - channel for the melt discharge to the profiling head; 4 - cylinder heaters; 5 - cylinder; 6 - screw; 7 - filling hopper; 8 - bunker; 9 - thrust bearing; 10 - reduction gear; 11 - spraying head; 12 - compressed air branch pipe; 13 - gas-polymer flow; 14 - shape-generating mandrel. Zones of screw: I - feeding (loading); II - compression (plasticization); III - squeezing (dosing). Electrization zone: 15 - high-voltage electrode; 16 - grounding electrode

Polymer fibrous materials (PFM) represent a set of the polymer fibers which are cohesively bonded in the places of contact and which form a fiber mass. Availability of the cohesive bond between the fibers release from the need to use additional processes (needlepunching, cross-linking, etc.) in PFM production. The melt blowing technology allows to impart the sorbing elements with shape stability and structural definiteness.

Density and diameter of fibers are the main PFM parameters which define their sorption characteristics. The material density can be adjusted within the range of $0.05-0.5 \mathrm{~g} / \mathrm{cm}^{3}$, while the diameter of fibers -5 to 500 microns (Fig. 3).
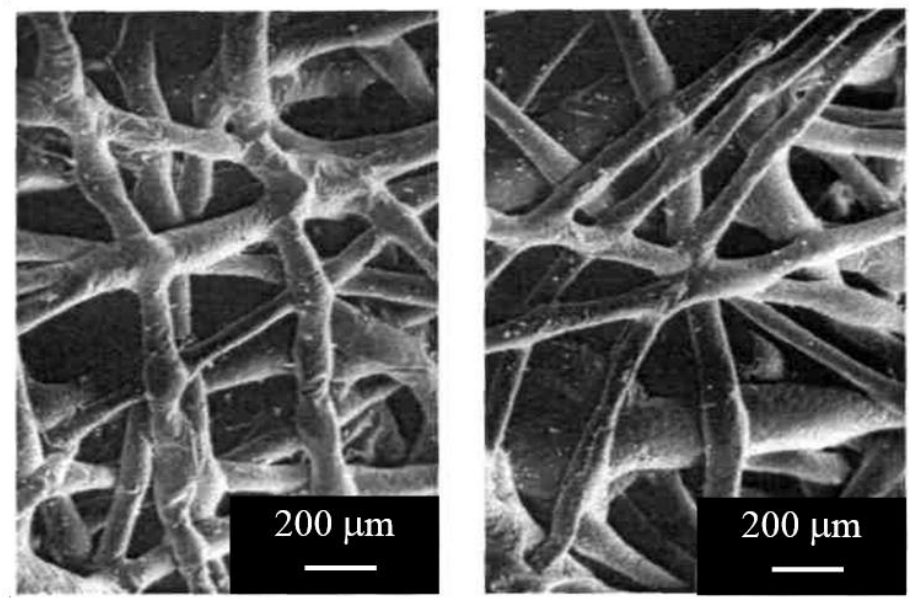

Figure 3 - Electron microscopic images of different areas of cross-sections of polymer fibrous melt-blown material

In certain cases, parameters of filter-adsorption treatment are determined by the nature of PFM fibrous matrix. For example, melt-blown materials consisting of thin lipophilic fibers (polyethylene, polypropylene) are excellent oil adsorbents [42]. High adsorptive capacity, adjustable distribution of fibers diametrically and by stacking density, large volume of cavities between fibers, permeability for liquids and gases are their characteristic features. Oil-retaining capacity of sorbents made of PFM in static conditions reaches $10 \mathrm{~kg}$ of oil per one kilogram of adsorbent, which considerably exceeds the same parameter of composite materials intended to gather petroleum products [43]. PFM made in the form of rolls, hoses and floating pillows serve as a means to remove oil from the water surface, protect the water body coasts and gather the petroleum products which have spilled in emergency situations at the enterprises and during transportation [44].

Adsorption capacity of prototypes of meltblown PFM based on polyolefins is as good as (and sometimes exceeds) the foreign composite nonwoven fabrics specifically intended to collect petroleum products. So, the melt blowing technology was used to produce the material based on thermoplastic polymer which consists of chaotically arranged fibers with a diameter of 5-20 microns and density of $0.01-0.2 \mathrm{~g} / \mathrm{cm}^{3}$ [45]. Absorption and 
retention of liquids in it occurs due to the capillaries formed by the fibers twisted in bundles and clusters. Content of such capillaries in the material reaches 60 $\%$, while the remaining $40 \%$ of fibers create the material base. Optimum absorbing ability of the material is created when the capillaries content in it is from $30 \%$ to $60 \%$. This material is capable to absorb the amount of liquid which is 40-50 times greater than its own weight.

\subsection{PFM modification with disperse sorbents}

Fibers modification with porous adsorbents allows to increase the PFM adsorptive capacity. The specific feature of such PFM structure is that the adsorbent particles are adhesively fixed to the fiber surface (Fig. 4).

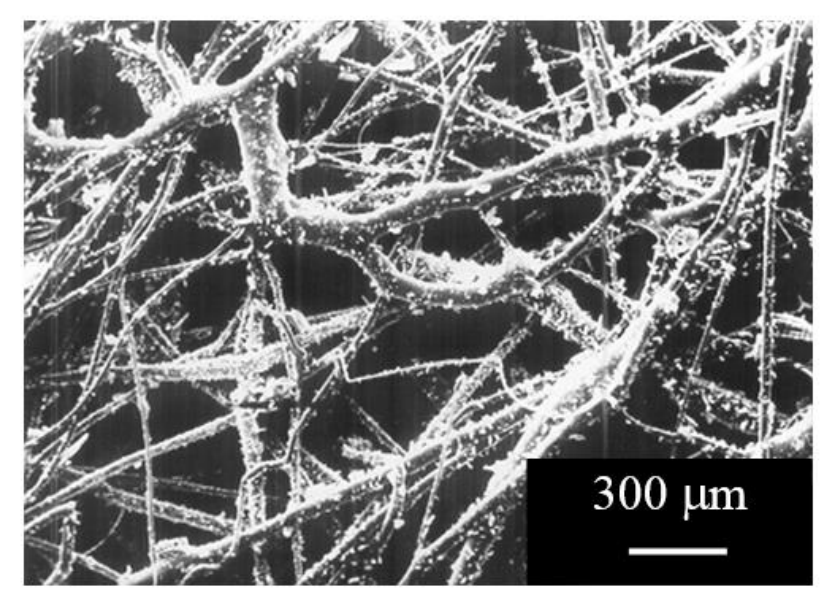

Figure 4 - Electron microscopic images of PFM based on high pressure polyethylene modified with activated charcoal particles (14 wt.\%).

It is inexpedient to process the dispersed adsorbents together with a polymer, since porous particles are encapsulated by the binders and lose their adsorptive capacity. If (at PFM forming) the particles are injected into the gas-polymer flow, then they come into adhesive contact with the fibers in viscous-flow state and (at hardening) are firmly fixed on the surface of fibers. This technology provides for the possibility to obtain materials with high adsorptive characteristics. Thus, PFM containing 1114 wt. \% of activated charcoal is three orders of magnitude higher than the one of the unmodified analog, and these PFM contain a considerable amount of sorption-active micro- and mesopores [39, page 163].

On the surface of PFM fibers (which are in viscous-flow state) it is also possible to adhesively fix the solid particles of mineral sorbent (for which purpose the modified bentonite clay is used) [46].
Polypropylene (PP) with filler (silicon dioxide $\mathrm{SiO}_{2}$, dispersion - 5-10 microns) with 8-16\% concentration in the fiber and bentonite clay particles (adhesively fixed to the particles of bentonite clay) with dispersion of 5-10 microns in the amount of 4-21 wt. $\%$ which are modified by soap stocks of fatty acids were used for producing specimens. The disperse filler was preliminary processed in the corona discharge field (intensity $-8-21 \mathrm{kV} / \mathrm{cm}$ ). As a result of polarization, an electret charge with the effective area density of $\sigma_{\text {eff }}=0.2-0.3 \mathrm{nC} / \mathrm{cm}^{2}$ is formed on the material fibers.

To assess the sorption capacity of the produced PFM, an emulsion of oil in water $(0.6 \%)$ had been created which was then passed through the developed multilayer PFM. The mass of emulsion was determined by weighing before and after filtration and, on this basis, the sorption capacity of the material was calculated (Fig. 5). 


\begin{tabular}{l|lr|ll|ll} 
& ISRA (India) & $=\mathbf{1 . 3 4 4}$ & IS $($ USA) & $=\mathbf{0 . 9 1 2}$ & ICV (Poland) & $=\mathbf{6 . 6 3 0}$ \\
Impact Factor: & ISI (Dubai, UAE) & $=\mathbf{0 . 8 2 9}$ & PUHL (Russia) & $=\mathbf{0 . 2 0 7}$ & PIF (India) & $=\mathbf{1 . 9 4 0}$ \\
& GIIF (Australia) & $=\mathbf{0 . 5 6 4}$ & ESJI (KZ) & $=\mathbf{4 . 1 0 2}$ & IBI (India) & $\mathbf{4 . 2 6 0}$ \\
& JIF & $=\mathbf{1 . 5 0 0}$ & SJIF (Morocco) & $=\mathbf{2 . 0 3 1}$ & & \\
\hline
\end{tabular}

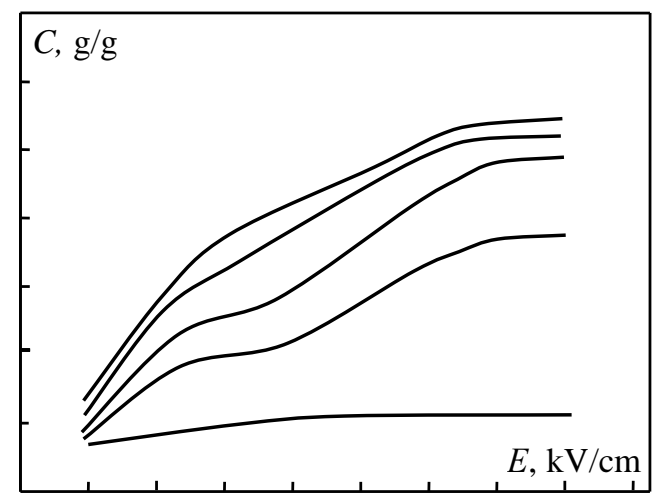

Figure 5 - The dependence diagram of oil sorption capacity $(C, \mathrm{~g} / \mathrm{g})$ of the combined PFM versus corona discharge field intensity at various contents of filler $\left(\mathrm{SiO}_{2}\right)$ and clay $(\mathrm{wt} . \% / \mathrm{wt} . \%)$ : $1-8 / 4 ; 2-10 / 5 ; 3-12 / 10 ; 4-15 / 20 ; 5-16 / 21$

As the result of the research it was established that combination of the disperse filler encapsulated in the fibers in the form of silicon dioxide $\mathrm{SiO}_{2}$ particles treated in the corona discharge and the particles of the modified bentonite clay applied on the surface of fibers significantly increases the efficiency of sorption of the oil dispersed in water. The largest sorption capacity was demonstrated by two PFM specimens made of PP with filler (silicon dioxide $\mathrm{SiO}_{2}$, concentration in the fiber $-15-16 \%$ ) polarized in the corona discharge field with intensity of 18 $\mathrm{kV} / \mathrm{cm}$ and the particles of the modified bentonite clay which are adhesively fixed on fibers in the amount of 20-21 wt.\% (curves 4 and 5 in Fig. 5).

Apparently, this is because of the fact that bipolar electret charge acquired by the fibers contributes to better wetting of the fiber surface due to deformation of solvation shells and disorientation of water dipole molecules. This results in improvement of hydrophobic properties of polymer fibers. Further increase in the amount of the applied fillers leads to an increase in sorbent weight and decreases its sorption capacity due to porosity reduction.

Thus, by using the additivity of properties, an effective combined sorbent [47] can be produced which summates the sorption properties of the modified polymer fibrous material and solid particles of bentonite clays adhesively fixed on the fiber surfaces.

\section{THE USE OF SECONDARY POLYMERS TO PRODUCE FIBROUS SORBENTS}

The repeated use of sorbents is possible only when gathering pure fractions of oil. Most often, after two-three regeneration cycles the sorbent capacity considerably decreases as its pores become clogged with dirt and heavy fractions and the structure of fibrous sorbent can be deformed. Change in the physical-chemical properties of the spilled oil as a result of its evaporation, oxidation, emulsification and other processes may be another reason for sorption deterioration. The increased content of gas, light fractions and emulsified water in oil often results in an increase in consumption of sorbent for the oil removal from the water surface.

Secondary raw materials can be used for sorbents production; in this case, such important quality indicator as retaining capacity of the sorbents made of secondary polymers may be even higher than the one of the sorbents made of primary raw materials.

The melt flow index (MFI) of the secondary polymer raw materials is very important for producing non-woven fibrous materials. Raw materials with low MFI values are used to produce coarse-fibered materials with high MFI values. Usually, these materials have low strength characteristics. Insignificant MFI reduction due to an increase in the gel fraction content is observed in the secondary polyethylene. At repeated processing of polypropylene, MFI goes up at the increase in the number of cycles; besides, at low processing temperatures (up to $220{ }^{\circ} \mathrm{C}$ ) slow MFI growth is observed at the increase in number of processing cycles. When the processing temperatures exceed $250{ }^{\circ} \mathrm{C}$, a drastic rise in MFI is observed (14-fold increase after 5 processing cycles at $T=290^{\circ} \mathrm{C}$ ) [48]. Sorption capacity of non-woven fabrics produced from the secondary PP (wastes of polypropylene bags) and used as sorbents is not worse than that of the materials made of primary PP. At the same time, retaining capacity of a sorbent produced from secondary PP is even better (up to $15 \%$ ) than that of the materials made of primary raw materials.

One of the most important advantages of the sorbents produced from fibrous materials is their high regenerative capability without considerable loss in sorption capacity at subsequent applications. Figure 6 shows the change in sorption capacity of PFM specimens produced from wastes of secondary 
thermoplastics depending on the number of regeneration cycles [49]. It can be seen that at repeated use their sorption ability remains at the level of $50-70 \%$ of the initial value.

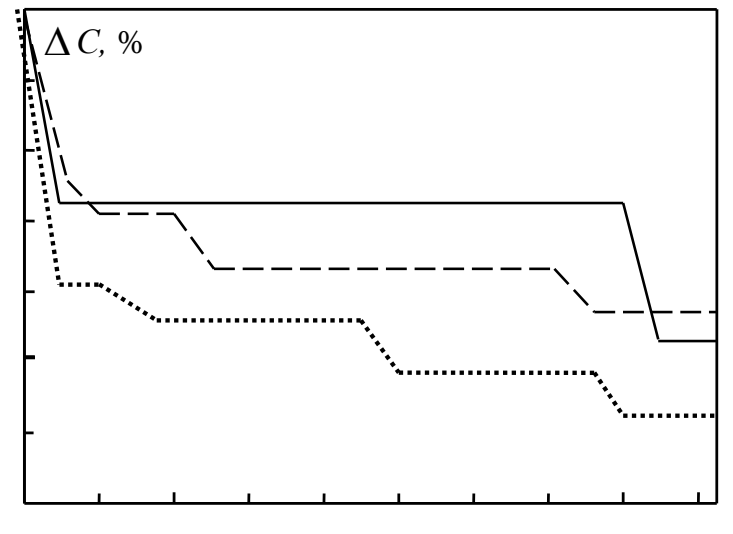

Figure 6 - Change in oil capacity $(\Delta \mathrm{C}, \%$ ) of PFM produced from wastes of secondary thermoplastics at repeated $(n)$ use: 1 - fibers from disposable medical syringes (polypropylene); 2 - fibers from plastic bottles (polyethyleneterephthalate); 3 - fibers from a mix of the used disposable syringe bodies and plungers (polyethylene and polypropylene)

\section{Conclusion}

It has been experimentally proven that meltblown materials of different types possess the oilretaining capacity in static conditions up to $50 \mathrm{~g} / \mathrm{g}$ and degree of extraction (from the water) of the emulsified oily substances up to $100 \%$, which exceeds the properties of the majority of the known sorption materials applied both for filtering and gathering of the spilled petroleum products. The studied patterns allow outlining a perspective to increase the efficiency of polymer fibrous materials as sorbents for oil and petroleum products. The regulation of structural parameters of the fiberporous materials produced by the melt blowing method, along with modification of polymer fibers in physical fields and introduction of target additives that will allow obtaining new highly efficient sorbents for gathering of oil and petroleum products may become a very promising direction.

The idea of modifying PFM in electric and magnetic fields is based on the existing technological possibility to impart the melt-blown materials with a number of additional properties, in particular, electret and magnetic ones. The field of electret charge contributes to electrostatic capture of the particles of contaminants and drops of oil emulsions, facilitates separation of organic liquids into polar and non-polar components and settling of pollutants, increases the system lipophilicity. The magnetic field generates the hydrodynamic pressure which breaks the solvate layers of drops of organic liquids and facilitates their coagulation. Oils and petroleum products trapping occurs not only by their adsorption on the surface of fibers, but also due to electrocapillary and magnetocapillary phenomena stimulated by the physical fields. Phase separation takes place as the result of disturbance in kinetic stability of water emulsions of organic substances and is accompanied with irreversible coagulation of drops and their strong retention in the pores of the sorption material. Therefore, it is necessary not only to take electric and magnetic effects into consideration, but also to initiate and apply them (in a targeted way) at development and creation of new sorbents.

\section{References:}

1. Mochalova OS, Gurvich LM, Antonova LM (2004) Methods of fighting with repair oil pollution of basins. Protection of environment in oil and gas complex (Защита окружающей среды в нефтегазовом комплексе). 2004, № 3 , p. $20-25$. 
2. Borodavkin PP, Kim BI (1981) Protection of environment at trunk pipelines building and operation. Moscow: Nedra, 1981, 160 p.

3. Kormak D (1989) Fighting with pollution on sea by oil and petrochemical products. Moscow: Transport, 1989, 364 p.

4. Samoilov NA (2001) Sorption method of breakdown elimination of oil and petrochemical products outflow. Moscow: Khimija, 2001, 189 p.

5. Roev GA (1987) Waste treatment and second use of petrochemical products. Moscow: Nedra, 1987, 224 p.

6. Kuzubova LI, Morozov SV (1992) Treatment of oil containing waste. Moscow: Khimija, 1992, $72 \mathrm{p}$.

7. Gerlakh SA (1985) Pollution of seas. Diagnosis and therapy. Leningrad: Gidrometeoizdat, 1985, $264 \mathrm{p}$.

8. Chursin FV, Gorbunov SV, Fedotova TV (2004) Repair oil spill: Localization facility and elimination methods. Fire safety (Пожарная безопасность), 2004, No 3, p. 176-189.

9. Kireeva NA, Onegova TS (2004) Biological cleaning of oil polluted basin. Water and ecology: problems and solutions (Водa $u$ экология: проблемь и решения), 2004, № 2, p. 67-69.

10. Radetic MM (2003) Recycled wool-based nonwoven material as an oil sorbent. Environ. Sci. and Technol., 2003, No 5, p. 1008-1012.

11. Karelin JaA, Vorob'eva GI (1957) Biochemical cleaning of oil containing waste. Chemistry and technology of fuels and oils (Химия и технология топлив и масел), 1957, № 10, p. 29-34.

12. Chikina NS, Mukhamedshin AV, Ankudinova $\mathrm{AV}$, et al. (2009) Reduction of ecological load from oil and petrochemical products spill with the help of sorbent based on foamed polyurethane and cereals waste. Herald of Kazan' technological university (Вестник Казанского технологического университета), 2009, № 6, p. 184-192.

13. Slisarenko FA (1971) Physical-chemical investigations and structure of nature sorbents. Saratov: Saratov State Pedagog. University. 1971, 110 p.

14. Slisarenko FA (1968) Physical-chemical investigations of natural sorbents. Saratov: Saratov State Pedagog. University. 1968, 76 p.

15. Chmutova KV (1967) Natural sorbents. Moscow: Nauka, 1967, 232 p.

16. Tarasevich JuI (1981) Natural sorbents in the processes of water cleaning. Kiev: Naukova Dumka, 1981, 207 p.

17. Stakhov EA (1983) Oil-containing sewage purification on enterprises for petrochemical products storage and transportation. Leningrad: Nedra, 1983, 263 p.
18. Glenda S, Roper WE, Gomez R (2003) Detection and monitoring of oil spills using hyper spectral imager. Conference on «GeoSpatial and Temporal Image and Data Exploitation 3». Proc.: SPIE, 2003, p. 233-240.

19. Arens VZh, Gridin OM (1997) Effective sorbents for elimination of oil overflow. Ecology and Industry of Russia (Экология и промьишленность Poccuu), 1997, No 2, p. 32-37.

20. Patent 63,971 Ukraina (2004), B01I 20/26, $\mathrm{C} 02 \mathrm{~F} 1 / 28$. Obtainment of sorbent for removal oil and petroleum products from water surfaces / Chumak OS, Belyaeva LS, Boiko NM, at al. Publ. 16.02.2004.

21. Akhmedeev VJa, Ipatova EL (1979) Problems and perspectives of porous sorbents use for sewage cleaning from organic compounds. Moscow: TsNII "Elektronika", 1979, 87 p.

22. Vorob'eva VV (2001) Improvement of protection system of sea waters and coastal zones from oil pollution. Materials of Sci.practical Conf. "Ecology-2001". Vladivostok: DVGMA, 2001, p. 54-57.

23. Patent 2,238,295 Russia (2004), C09K 3/00, 3/32. Material and method of treatment pollutions of oil and/or petrochemical products / Kirchanov IV, Akhmetshina AG, Zakharov VF, et al. Publ. 16.02.2004.

24. Khlyostkin RN (1998) Investigation of absorbent properties of sorbents for elimination of petroleum products overflow. Heads of reports on II Intern. Conf. "Solving of ecological problems in motor transport complex". Moscow, 1998, p. 76-78.

25. Samoilova NA, Khljostkin RN, Shemetov AV (1999) Physical-chemical basis of oil gathering from water surface by mats and absorbing envelopes with fibrous sorbents. Heads of reports on conf. "Problems, methods and protection of environment from oil and petroleum products pollution". Moscow: GUPVIMI, 1999, p. 122-126.

26. Makarova YuA (2011) Decrease of sewage influence of oil and oil-chemical enterprises on water objects by using sorbents based on wastes of agrotechnic complex: $\mathrm{PhD}$ thesis. Kazan' state technological university, 2011, 168 p.

27. Nizimov RKh (2011) Purification of oil polluted waters by sorption materials based on waste of walk-mill manufacture: $\mathrm{PhD}$ thesis. Kazan' state technological university, 2011, $160 \mathrm{p}$.

28. Sobgaida NA (2011) Methodology of sewage purification of chemical and oil-chemical industry by phytosorbents and modified waste of agrotechnic complex: $\mathrm{PhD}$ thesis. Kazan' state technological university, 2011, $303 \mathrm{p}$.

29. Shaikhiev IG (2011) Ecology-technological base of modification and use of wool- and flaxprocessing waste for polluted water cleaning: 


\begin{tabular}{|c|c|c|c|c|c|c|}
\hline Impact Factor: & $\begin{array}{l}\text { ISRA (India) } \\
\text { ISI (Dubai, UAE } \\
\text { GIF (Australia) } \\
\text { JIF }\end{array}$ & $\begin{array}{l}=1.344 \\
=0.829 \\
=0.564 \\
=1.500\end{array}$ & $\begin{array}{l}\text { SIS (USA) } \\
\text { PИНЦ (Russia) } \\
\text { ESJI (KZ) } \\
\text { SJIF (Morocco }\end{array}$ & $\begin{array}{l}=0.912 \\
=0.207 \\
=4.102 \\
=\mathbf{2 . 0 3 1}\end{array}$ & $\begin{array}{l}\text { ICV (Poland } \\
\text { PIF (India) } \\
\text { IBI (India) }\end{array}$ & $\begin{array}{l}=6.630 \\
=1.940 \\
=4.260\end{array}$ \\
\hline
\end{tabular}

$\mathrm{PhD}$ thesis. Kazan' state technological university, 2011, $335 \mathrm{p}$.

30. Rozman HD, Ahmadhilmi KR, Abubakar A (2004) Polyurethane - oil palm empty fruit bunch (EFB) composites: the effect of EFBG reinforcement in mat foam and isocyanate treatment on the mechanical properties. Polymer Test., 2004, No 5, p. 559-565.

31. Moawed EA (2004) Synthesis and application of Alizarin red $\mathrm{S}$ bonded polyurethane foam for separation and preconcentration of trace amounts of some metal ions in wastewater. J. Indian Chem. Soc. 2004, No 5, p. 395-401.

32. Khlyostkin RN, Samoilov NA (2000) About elimination of oil overflow using vegetable waste. Oil economy (Нефтяное хозяйство), 2000, No 7, p. 84-85.

33. Patent 2,198,987 Russia (2003), У02B 15/04. Sorbent for complex purification of water and soil surface from petroleum products and heavy metals / Kireichyova LV, Khokhlova OB. Publ. 20.02.2003.

34. Patent 2,231,498 Russia (2004), C02F 1/28, B01I 20/30. Method of liquid purification from oil and petroleum products / Gorin VM, Tokareva SA, Avakova VD. Publ. 27.06.2004.

35. Alekseeva TP, Burmistrova TI, Perfil'eva VD (2002) Physics and chemistry of peat in solving ecology problems. Heads of reports on Intern. Sympos. "Solving of ecological problems", Minsk: Tonpik, 2002, p. 24-27.

36. Artyomov AV (2004) Up-to-date technologies of purification oil pollutions. Oil. Gas. Industry (Нефть. Газ. Промышленность), 2004, o 5, c. 24-27.

37. Kholodenko VP (2001) Development of biotechnological methods of elimination of oil pollution in surrounding. Russian Chemical Journal, 2001, No 5-6, p. 135-141.

38. Oil sorbents - materials for gathering oil and petroleum products from water surface [Electronic resource]. - Access mode: http://sorboil.su/neftyanue-sorbentu - Access date: 01.06.2018.

39. Goldade VA (2000) Polymer fibrous melt blown materials / VA Goldade, AV Makarevich, LS Pinchuk, et al. - Gomel: MPRI of NAS of Belarus, 2000, 260 p.

40. Pinchuk LS (2002) Melt Blowing: Equipment, Technology, and Polymer Fibrous Materials / LS Pinchuk, VA Goldade, AV Makarevich, VN
Kestelman. - Springer-Verlag: BerlinHeidelberg-New York, 2002, 224 p.

41. Kravtsov AG, Marchenko SA, Zotov SV (2008) Polymer fibrous filters for overcoming aftermath of junctures. Ed. AG Kravtsov. Gomel: P.O. Sukhoi Gomel State Technical University, 2008, $280 \mathrm{p}$.

42. Vertyachikh IM, Zhukalov VI (2011) Polymer fibrous melt blown materials for elimination accidents with oil and petroleum products overflow. Junctures: Education and Science (Чрезвычайные ситуации: образование и наука), 2011, vol. 6, No 1, p. 53-68.

43. Plevachuk VG, Makarevich AV, Parkalova EI, Goldade VA (1997) Structure and absorption characteristics of melt blown fibrous polymer materials. Chemical fibers (Химические волокна), 1997, No 1, p. 31-34.

44. Vertyachikh IM, Goldade VA, Makarevich AV, Pinchuk LS (1997) Use of fibrous polymer materials for elimination of oil overflows induced by aftermath of natural disasters // Heads of reports on Intern. Sympos. "Element. Building. Safety (Стихия. Строительство. Безопасность)"”. Vladivostok, 1997, p. 358.

45. Patent 2,126,725 Russia (1999), B01J 20/22. Absorbing fibrous-porous material / AI Chernorubashkin, AV Sikanevich, VF Gaiduk, et al. Publ. 27.02.1999.

46. Bobrysheva SN, Zhukalov VI, Zhurov MM (2017) Combined sorbent of oil and petroleum products on the base of polymer fibrous melt blown material. Herald of Gomel State Technical University (Вестник ГГТУ им. П.О.Сухого), 2017, No 4, p. 90-96.

47. Patent 21,088 Belarus (2017), B01J 20/00. Combined sorbent for gathering oil and petroleum product. Vertyachikh IM, Sutor'ma II, Bobrysheva SN, et al. Publ. 30.06.2017.

48. Grishchenko VV, Goldade VA, Kudyan SG, Gaiduk VF (2006) Preparation of thermoplastic polymer waste for reprocessing into nonwoven fibrous materials. Materials. Technologies. Tools (Материаль, технологии, инструменты ), 2006, vol. 11, No 6, p. 78-83.

49. Sirotkina EE, Novoselova LYu (2005) Material for absorption cleaning water from oil and petroleum products. Chemistry in the interests of stable progress (Химия в интересах устойчивого развития), 2005, vol. 13, No 3, p. 359-377. 